\title{
Effect of basil oil (Ocimum basilicum) on nonspecific immune response of Nile-tilapia (Oreochromis niloticus)
}

Ahmed M.M. El-Ashram*; Abeer A.M. Afifi** and Saleh F. Sakr**

* Fish Diseases and Health Dept., Faculty of Fish Resources, Suez Univ., Egypt.

** Fish Diseases Dept., Central Lab. for Aquaculture Research, Abbassa, Egypt.

\section{ABSTRACT}

Bacterial fish diseases are considered as major constraint in aquaculture production. The use of natural phytochemicals is promising in aquaculture because they are safe for the environment and human health, biocompatible and biodegradable. The present study was carried out to investigate the effect of Ocimum basilicum oil on the non-specific immune response of Nile-tilapia (Oreochromis niloticus) and resistance against Aeromonas hydrophila infection.

A hundred and eighty Nile-tilapia (Oreochromis niloticus) $(20 \pm 2 \mathrm{~g} /$ fish $)$ were randomly distributed and divided into four equal groups in well prepared glass aquaria supplied with continuous areation. The $1^{\text {st }}$ group was assigned as non-treated control group. The $2^{\text {nd }}, 3^{\text {rd }}$ and $4^{\text {th }}$ groups were fed on treated ration with basil oil at concentration of $0.25,0.5$ and $1 \%$ of basil oil $/ \mathrm{kg}$ diet for 42 days, respectively.

The obtained results showed that the orally administrated basil oil has been shown to enhance the non-specific immune response in the treated fish (hematocrit levels, respiratory burst activity, serum lysozyme and serum bactericidal activity) all over the experiment period in compared with the control group. Also, significant decrease in total bacterial count of fish muscles in compared with control group. Mortality rates post challenge infection, were significantly lesser in treated groups in compared with control group. It was observed that the mortalities among the challenged fish are dose related. These findings are supportive of the potential of basil oil use as ecofriendly alternative measures of disease prevention for sustainable aquaculture. 
Keywords: basil oil, Oreochromis niloticus, non-specific immune response, Aeromonas hydrophila.

\section{Introduction}

Aquaculture has an important role in the development of many national economics and in meeting the rising demand for animal protein (Haylor and Bland, 2001). Nile-tilapia production is considered to be the fastest growing sector of the Egyptian fish farming industry has spread to several countries all over the world (Veenstra et al., 1992 and Woo and Bruno, 1999).

Use of antibiotics in treatment of infectious disease has led to the development of the resistant strains is rather difficult, non-effective, costly and also involves environmental hazards (Cañada $\boldsymbol{e t} \boldsymbol{a l}$., 2009). The antibiotics also may reduce fish growth and immune response (Chakraborty and Hancz, 2011). For instance, the development of antibiotic resistance was reported for several pathogens including Aeromonas hydrophila, A. salmonicida, Edwardsiella tarda, E. icttaluri, Vibrio anguillarum, and Yersinia ruckeri (Petersen et al., 2002). In the development of alternative practices for disease management in finfish culture, attention has been diverted to finding immunostimulant substances from plant sources that are safe for both fish and humans (Chakraborty and Hancz, 2011).

Dietary supplementation of immunostimulants in aquafeed is considered one of the most promising methods strengthening fish defense mechanism in aquaculture (Harikrishnan et al., 2010). Sweet basil (Ocimum basilicum L.) is widely cultivated in many countries of the world and extensively used for food, perfumery, cosmetics, pesticides, medicine, and traditional rituals because of their natural aroma and flavor and other properties (Alburquerque, 1996).

The medicinal and aromatic properties of basil are associated with the presence of an essential oil that accumulates in the largest amount in its leaves and flowers. The main constituents of essential oils are mono- and sesquiterpenes and some of these compounds have shown antibacterial, antifungal and antioxidant activities (Lee and Ahn, 1998). The fresh and dried basil herb is used as an aromatic spice and a source of essential oil, and its main components are also used as plant drugs, since it has antimicrobial (Koba et al., 2009) and fungistatic activity (Dambolena et al., 2010); moreover, basil oil and 
its pure components have antimutagenic activity (Stajković et al., 2007).

Lina and Gonzalo (2010) reported that the major compounds of $O$. basilicum essential oil were $\beta$-linalool (46.67\%) and estragole (27.43\%). Ismail (2006) found that the major terpenes present in $O$. basilicum are linalool (44.18\%), cineole (13.65\%), eugenol (8.59\%), isocaryophyllene $(3.10 \%)$, methyl cinnamate $(4.26 \%)$, and acubebene $(4.97 \%)$.

According to our knowledge there are few data available in the literature about the effect of basil oil on the immune response and diseases resistance of Nile-tilapia. Therefore the aim of the current investigation was to throw light on the influence of different concentrations of basil oil on nonspecific immune response and diseases resistance of Nile-tilapia to Aeromonas hydrophila infection.

\section{Materials and Methods}

This study was conducted at Central Laboratory for Aquaculture Research at Abbassa, Agriculture Research Center, Ministry of Agriculture, Egypt.

\section{Experimental fish}

An apparently healthy Nile-tilapia (Oreochromis niloticus) weighting $20 \pm 2 \mathrm{~g} /$ fish were obtained from earthen fish farm. They were maintained in glass aquaria $(60 \times 50 \times 70 \mathrm{~cm})$ filled with dechlorinated tap water which continuously aeration using air pumping compressors. The fish were fed on a commercial fish ration. They were acclimatized to the laboratory conditions for 15 days before the start of the experiment. Moreover, a $12 \mathrm{~h}$ dark: $12 \mathrm{~h}$ light photoperiod was provided. The water temperature was kept at $22 \pm 2{ }^{\circ} \mathrm{C}$ throughout the experiment. About half of the water was changed daily in all the experimental aquaria. The fecal matters were siphoned out once daily. The biomass of the fish in each aquarium was measured at the beginning of the experiment and after each sampling to adjust the daily ration.

\section{Diet preparation:}

A standard commercial basal diet (crude protein 30\%) was crushed and supplemented with basil oil at the concentrations of $0,0.25,0.5$ and $1 \%$ of basil $/ \mathrm{kg}$ diet. The diets were reformed into pellets, air dry and stored at $4^{\circ} \mathrm{C}$ for the feeding experiment. 


\section{Experimental design:}

A hundred and eighty $O$. niloticus were randomly and equally divided into four equal groups in twelve glasses aquaria as mentioned before, in three replicates, each contained 15 fish. The first group $\left(\mathrm{T}_{1}\right)$ fish was fed with the control diet (not treated basal diet). The second, third and fourth groups were fed on basal diet contained 0.25, 0.5 and $1 \%$ of basil oil $/ \mathrm{kg}$ diet $\left(\mathrm{T}_{2}, \mathrm{~T}_{3}\right.$ and $\left.\mathrm{T}_{4}\right)$, respectively. The fish were hand-fed for 42 days at rate of $2 \%$ of their body weight. Fish and blood samples were taken at $7^{\text {th }}, 14^{\text {th }}, 28^{\text {th }}, 35^{\text {th }}$ and 42 th day of the experiment.

\section{Blood and serum sampling:}

At the $7^{\text {th }}, 14^{\text {th }}, 28^{\text {th }}, 35^{\text {th }}$ and 42 th day of the feeding experiment, the fish were anaesthetized by immersing the fish in water containing $0.1 \mathrm{ppm}$ tricaine methane sulphonate (MS-222). Blood-samples were collected from the caudal vein of fish, by using needles previously rinsed in heparin $(15 \mathrm{unit} / \mathrm{ml})$ for the evaluation of hematocrit value and respiratory burst activity. For serum separation the nonheparinized blood was centrifuged at $3000 \mathrm{rpm}$ for 15 minutes. The serum was stored at $-20^{\circ} \mathrm{C}$ in screw cap glass vials until used for lysozyme and serum bactericidal activities

\section{Hematocrit level:}

Hematocrite capillary tubes previously rinsed in heparin (15unit/ml) were filled $2 / 3$ with whole blood and centrifuged in hematocrite centrifuge for 5 minutes. The percentage of erythrocyte volume is measured by hematocrite tube reader (Schaperclaus $\boldsymbol{e t}$ al. 1992).

\section{Respiratory burst activity by measuring Nitro Blue Titrazolium (NBT):}

$0.1 \mathrm{ml}$ blood was placed into microtiter plate then equal amount of $0.2 \%$ NBT solution was added and incubated for $30 \mathrm{~min}$ at room temperature, $0.1 \mathrm{ml}$ of NBT blood cell suspension was taken and added to a glass tube contain $1 \mathrm{ml} \mathrm{N}, \mathrm{N}$ - dimethyl formamide and centrifuged for 5 minutes at $3000 \mathrm{rpm}$, the supernatant fluids was read in spectrophotometer at $620 \mathrm{~nm}$ in $1 \mathrm{ml}$ cuvettes (Siwicki et al. 1985).

\section{Serum Lysozyme activity:}

The lysozyme activity was measured using photoelectric colorimeter with attachment for turbidity measurement. A series of dilution was prepared by diluting the standard lysozyme from hen 
egg-white (Fluka, Switzerland) and mixed with Micrococcus lysodeikticus (ATCC No. 1698 Sigma) suspension for establishing the calibration curve. Ten $\mu l$ of standard solution or serum were added to $200 \mu \mathrm{l}$ of Micrococcus suspension (35 mg of Micrococcus dry powder/95 $\mathrm{ml}$ of $1 / 15 \mathrm{M}$ phosphate buffer and $5.0 \mathrm{ml}$ of $\mathrm{NaCl}$ solution). The changes in the extinction were measured at $546 \mathrm{~nm}$ by measuring the extinction immediately after adding the solution which contained the lysozyme (start of the reaction) and after a $20 \mathrm{~min}$ incubation of the preparation under investigation at $40^{\circ} \mathrm{C}$ (end of the reaction). The lysozyme content is determined on the basis of the calibration curve and the extinction measured (Schaperclaus $\boldsymbol{e t}$ al. 1992).

\section{Serum bactericidal activity (SBA):}

Bacterial cultures of $A$. hydrophila were centrifuged and the pellet was washed and suspended in phosphate buffer saline. The optical density of the suspension was adjusted to 0.5 at $546 \mathrm{~nm}$. This suspension was serially diluted $(1: 10)$ with PBS five times. Serum bactericidal activity was determined by incubating $2 \mu 1$ of this diluted bacterial suspension with $20 \mu \mathrm{l}$ of serum in a micro-vial for $1 \mathrm{~h}$ at $37^{\circ} \mathrm{C}$. In the bacterial control group, phosphate buffer saline replaced the serum. After incubation, the number of viable bacteria was determined by counting the colonies after culturing on TSA plates for $24 \mathrm{hrs}$ at $37^{\circ} \mathrm{C}$.

\section{Total bacterial count of fish muscle:}

Three fish samples from each replicate were collected randomly and under complete aseptic condition the fish samples were dissected, weighted one gram of muscle and grinding with $9.0 \mathrm{ml}$ sterile saline. Six-fold serial dilutions of this suspension prepared in saline and 0.1 $\mathrm{ml}$ of each dilution was spread onto Tryptone-glucose yeast agar medium as recommended by APHA (1995). The colonies were counted after incubation at $30^{\circ} \mathrm{C}$ for 48 hours.

\section{Challenge test:}

At the end of the feeding experiment, the fish of each group were divided into three subgroups (distributed in 3 aquaria). The fish was challenged intraperitoneally with $0.5 \mathrm{ml} 10^{7}$ cells of $24 \mathrm{~h}$ cultures of live A. hydrophila. The challenged fish were kept under observation for 14 days. The moribund fish was used for bacterial re-isolation . The mortalities were recorded and the relative level of protection 
(RLP) among the challenged fish was determined according the following equation:

RLP $=1$-[percentage of treated mortality/ percentage of control mortality] x100.

\section{Statistical analysis:}

Statistical analysis was performed using the one way analysis of variance (ANOVA). It was performed with SPSS statistical software (version 10.0, SPSS). The data were subjected for test of homogeneity of variances and Duncan post-hoc test. Data were considered significantly different when $\mathrm{P}<0.05$.

\section{Results}

\section{Heamatocrite level:}

The present study revealed that the heamatocrite values were significantly increased after first week in basil oil treated groups T2, T3 andT4 (49, 55and 55\% respectively), in compared with the control $(31 \%)$. Also, there were significance differences in heamatocrite values after two, four and six weeks of feeding in all treatments in comparison with control fig (1). In addition to, there was not significance between $\mathrm{T} 3$ and $\mathrm{T} 4$ values.

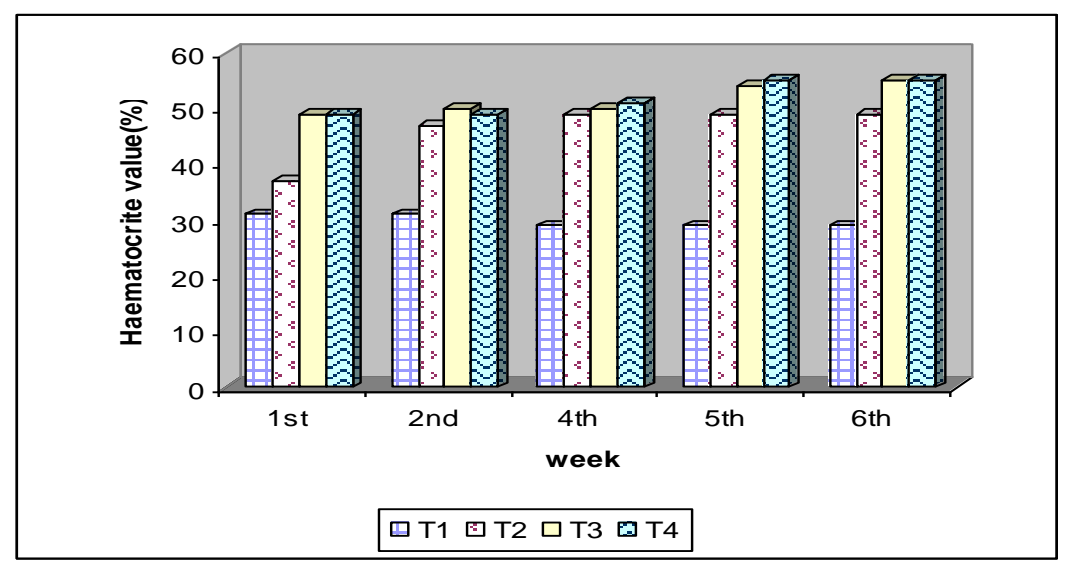

Fig (1): Effect of diet supplemented with Ocimum basilicum L.oil on Heamatocrite value in $O$. niloticus during feeding experiment. (Means carrying different superscripts are significant at $(\mathrm{p} \leq 0.05)$. $\mathrm{T} 1=$ basal diet free from basil oil. $\mathrm{T} 2=$ Fish fed basal diet supplemented with $0.25 \%$ basil oil. T3= Fish fed basal diet supplemented with $0.5 \%$ basil oil. T4= Fish fed basal diet supplemented with $1 \%$ basil oil). 


\section{Respiratory burst activity by measuring nitroblue titrazolium activity (NBT):}

The result in fig (2) illustrated that the value of NBT was significantly increased with $\mathrm{T} 2, \mathrm{~T} 3$ andT4 reached to $1.14 \pm 0.029$, $1.285 \pm 0.04$ and $1.378 \pm 0.09 \mathrm{mg} / \mathrm{ml}$ respectively), when compared with the control $(0.833 \pm 0.01 \mathrm{mg} / \mathrm{ml})$. In addition to, there was significant difference after two, four and six weeks of feeding experiment in all treatments. Also, NBT was increased by increasing the concentration of basil oil.

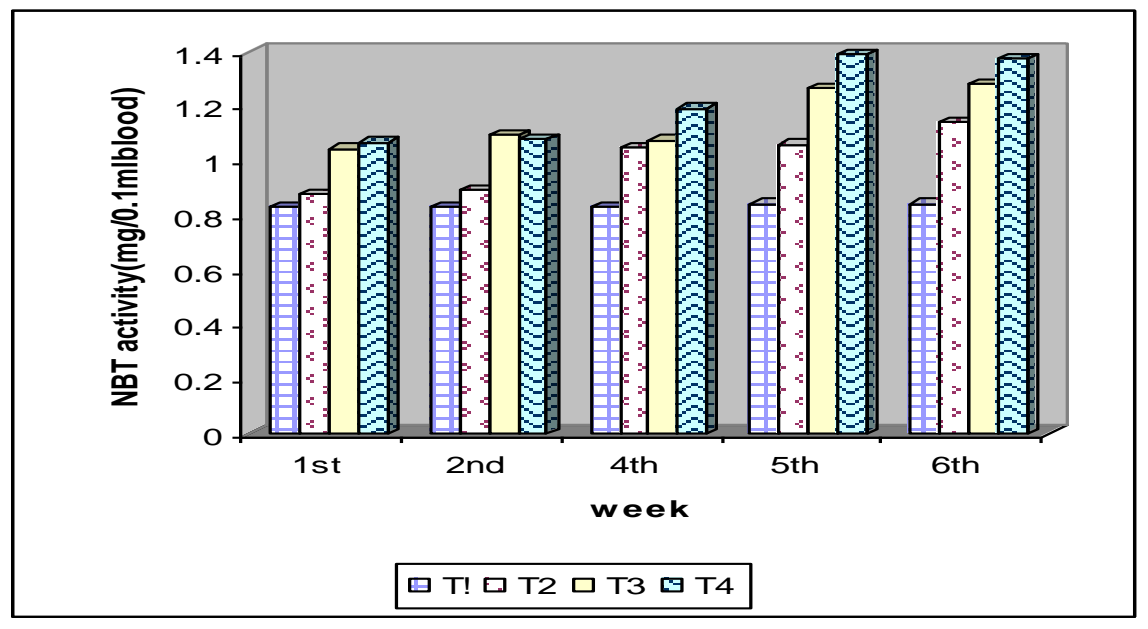

Fig (2): Effect of diet supplemented with Ocimum basilicum L. oil on respiratory burst by using Nitro Blue Tetrazolium activity (NBT) $\mathrm{mg} / \mathrm{ml}$ in $O$. niloticus during feeding experiment. (Means carrying different superscripts are significant at $(\mathrm{p} \leq$ $0.05) . . \mathrm{T} 1=$ basal diet free from basil oil. $\mathrm{T} 2=$ Fish fed basal diet supplemented with $0.25 \%$ basil oil $. \mathrm{T} 3=$ Fish fed basal diet supplemented with $0.5 \%$ basil oil. T4= Fish fed basal diet supplemented with $1 \%$ basil oil).

\section{Lysozyme activity:}

At six ${ }^{\text {th }}$ week of feeding experiment, serum lysozyme activity was significantly increased with $\mathrm{T} 2$ followed by $\mathrm{T} 3$ and $\mathrm{T} 4$ reached to $2.46 \pm 0.0057,3.4 \pm 0.16$ and $3.67 \pm 0.042 \mu \mathrm{g} / \mathrm{ml}$. when compared with the control group1.217 $\pm 0.14 \mu \mathrm{g} / \mathrm{ml}$ represented in fig (3). There was not significance difference of serum lysozyme activity between $\mathrm{T}_{3}$ and $\mathrm{T}_{4}$ at six $^{\text {th }}$ weeks. Moreover, serum lysozyme was significantly increased by increasing the concentration of basil oil. 


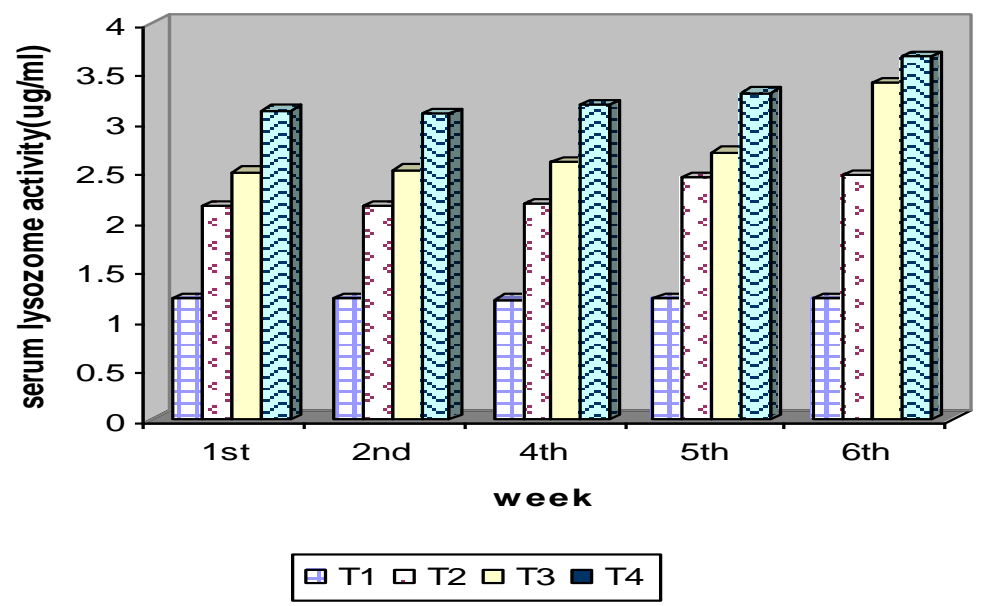

Fig (3): Effect of diet supplemented with Ocimum basilicum L. oil on serum lysozome activity in $O$. niloticus during feeding experiment. (Means carrying different superscripts are significant at $(\mathrm{p} \leq 0.05)$.. $\mathrm{T} 1=$ basal diet free from basil oil . $\mathrm{T} 2=$ Fish fed basal diet supplemented with $0.25 \%$ basil oil $. \mathrm{T} 3=$ Fish fed basal diet supplemented with $0.5 \%$ basil oil. T4= Fish fed basal diet supplemented with $1 \%$ basil oil).

\section{Serum bactericidal activity (SBT) against $A$. hydrophila:}

The present results revealed that, orally administrated basil oil groups has been shown to enhance the bactericidal activity significantly in compared with the control group fig ( 4 ). At the six ${ }^{\text {th }}$ week of feeding experiment, the viable bacterial counts of $A$. hydrophila were significantly lower in $\mathrm{T} 2$, $\mathrm{T} 3$ and $\mathrm{T} 4$ with an average values $3.7 \times 10^{4} \pm 1.4,2.2 \times 10^{4} \pm 0.57$ and $4.4 \times 10^{3} \pm 0.006 \mathrm{cfu} / \mathrm{ml}$ serum respectively when compared with $\mathrm{T}_{1}\left(1.5 \times 10^{5} \pm 28.8 \mathrm{cfu} / \mathrm{ml}\right)$. The serum bactericidal activity against $A$. hydrophila, was significantly higher with $\mathrm{T} 2, \mathrm{~T} 3$ and $\mathrm{T} 4$, than the control group. The number of bacterial colonies, in $\mathrm{T}_{2}, \mathrm{~T}_{3}$ and $\mathrm{T}_{4}$ was significantly lower than the control. 


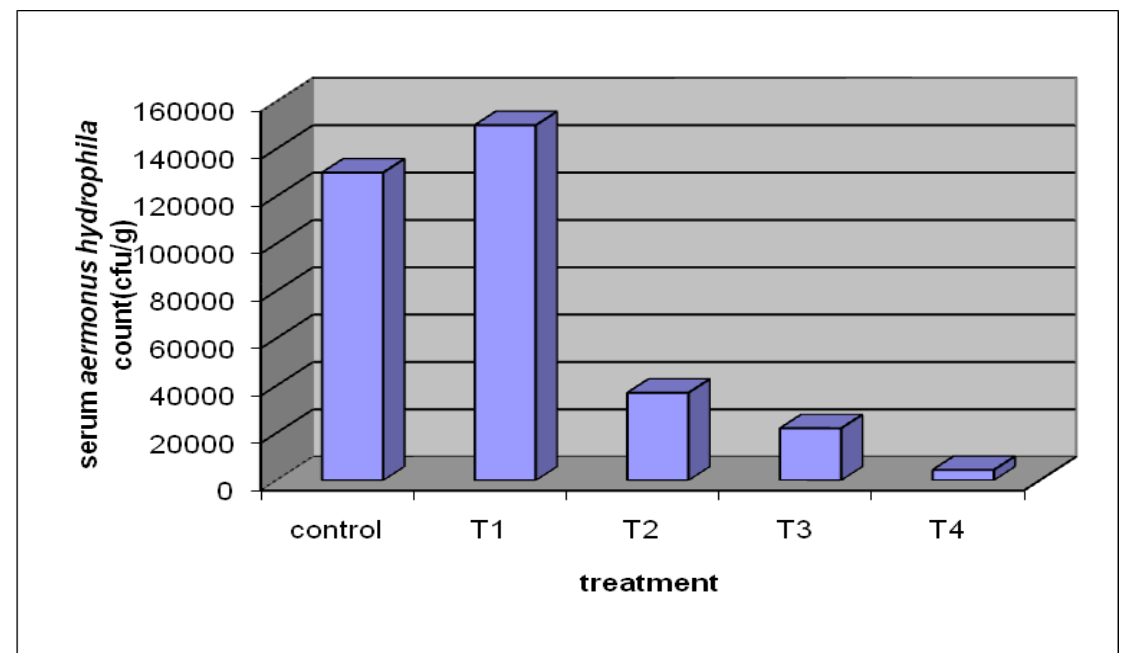

Fig (4): Effect of Ocimum basilicum L. oil supplemented diet on Serum bactericidal activity of $O$. niloticus against $A$. hydrophila during feeding experiment (Means carrying different superscripts are significant at $(\mathrm{p} \leq 0.05) . \mathrm{T} 1=$ basal diet free from basil oil . T2= Fish fed basal diet supplemented with $0.25 \%$ basil oil. T3 $=$ Fish fed basal diet supplemented with $0.5 \%$ basil oil. T4= Fish fed basal diet supplemented with $1 \%$ basil oil).

\section{Total bacterial count of fish muscle:}

Dietary supplementation of basil oil led to significant decrease in total bacterial count in fish muscle in all treated groups in comparison with control group fig ( 5 ). The total bacterial count of fish muscle at the end of experiment significantly decreased with $\mathrm{T} 2$ followed by T3 and T4 (6.1x102 $\pm 4.04,2.1 \times 102 \pm 1.76,6.9 \times 10 \pm 2.9$ cfu/g respectively) when compared with $\mathrm{T} 1(1.7 \times 103 \mathrm{cfu} / \mathrm{g})$. It was observed that the total bacterial count was decreased by increasing the concentration of basil oil in diet. 


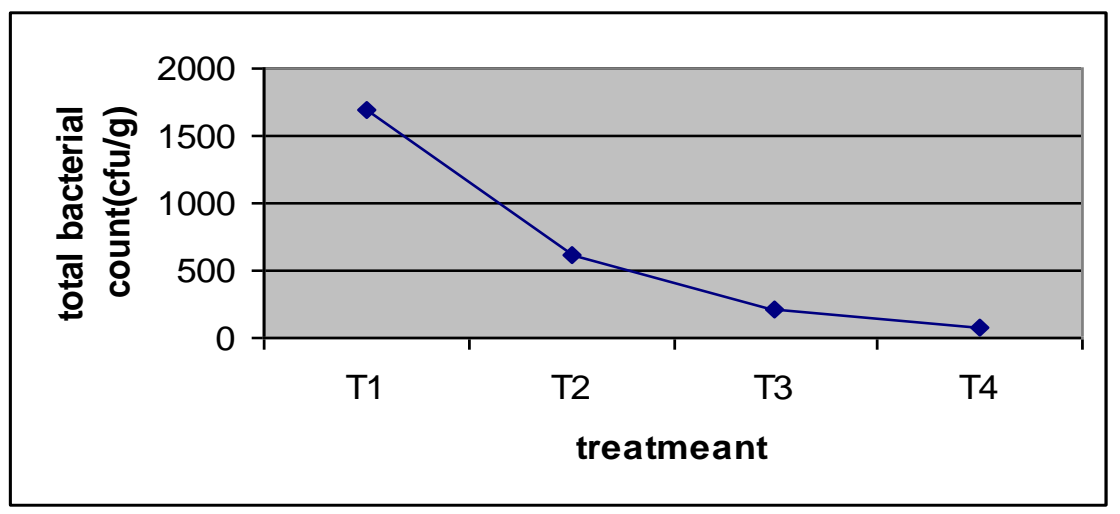

Fig (5): Effect of Ocimum basilicum L oil supplemented diet on total bacterial count of $O$. niloticus muscle during feeding experiment. (Means carrying different superscripts are significant at $(\mathrm{p} \leq 0.05)$.. $\mathrm{T} 1=$ basal diet free from basil oil . $\mathrm{T} 2=$ Fish fed basal diet supplemented with $0.25 \%$ basil oil $. \mathrm{T} 3=$ Fish fed basal diet supplemented with $0.5 \%$ basil oil. T4= Fish fed basal diet supplemented with $1 \%$ basil oil).

\section{Challenge test:}

It was observed that the mortalities among the challenged fish are dose related. Mortality rates post challenge infection, were significantly lesser in treated groups than in control group (Table 1). The mortality rates in experimental groups were $70,50,25$ and $0 \%$ for T1, T2, T2, T3 and T4, respectively. Relative level of protection (RLP) due to feeding diet supplemented with basil oil against $A$. hydrophila in T4 was higher than in other treatments (100\%) and dose related in the other treatments to $0,29,65$ for $\mathrm{T} 1, \mathrm{~T} 2$ and $\mathrm{T} 3$ respectively. 
Table (1): Mortality rate and Relative level of protection in treated O. niloticus due to challenge with A. hydrophila.

\begin{tabular}{ccc}
\hline Treatment & \multicolumn{2}{c}{ A. hydrophila } \\
\cline { 2 - 3 } & Mortality\% & RLp\% \\
\hline T1 & 70 & 0 \\
T2 & 50 & 29 \\
T3 & 25 & 65 \\
T4 & 0 & 100 \\
\hline
\end{tabular}

\section{Discussion}

Fish under intensive culture conditions will be badly affected and often fall prey to different microbial pathogens that have been treated with chemotherapeutic substances of which antibiotics were intensively used. These curative substances produce the problem of bacterial drug fastness on one hand and the public health hazards on the hands (Rebortson et al., 2000). These awaited drawbacks enforced the fish pathologists to seek for other alternatives; the use of natural immunstimulants in the fish culture for the prevention of diseases is a promising new development (Anderson, 1992; Siwicki et al., 1994 and Sakai, 1999). Natural immunstimulants are biocompatible, biodegradable and safe for the environment and human health. Moreover, they possess an added nutritional value. To improve aquatic animal health and prevent diseases in aquaculture, the application of immune-stimulants such as natural plant extracts is considered a new and friendly method for prevention of fish diseases (Jian and $W u, 2003$; Sivaram et al., 2004).

Basil oil is a mixture of numerous compounds and its composition is extremely rich and varied. Some constituents of the volatile oil distilled from the basil herb, such as linalool, 1,8-cineole, eugenol, or camphor, show documented biological activity Linalool, which is the dominant compound of the oil derived from European basil varieties (Marotti et al. 1996; Sifola and Barbieri 2006; SeidlerLożykowska and Król 2008; Dzida 2010), has antiinfammatory, antibacterial antiviral, antifungal, and relaxant properties (Peana $\boldsymbol{e t}$ al. 2004; Özek et al. 2010). Compounds in basil (Ocimum basilicum) 
oil have potent antioxidant, antiviral, and antimicrobial properties, and potential for use in treating cancer (Bozin et al., 2006). The immune system is complex system, to protect the host from invading and to eliminate disease. Immunodulator are being used as an adjuvant in condations of immunodeficiency in cancer and other immuno deficiency syndrome (Mathew and Kuttan, 1999). In the present study Ocimum basilicum showed increasing in heamatocrite value. The elevated hematocrit-value could explain the efficiency of the used basil oil on the health of the fish status. The increase of hematocrit may attribute to its bioactive compound. Hassanpouraghdam etal., (2010) and Naguyen etal., (2008) reported that Ocimum basilicum contain different bioactive compounds such as glycoside, mucilage, proteins, aminoacids, tannins, phenolic compound, ritepenoids, steroids and flavonoids.

The NBT was significantly increased (T2, T3and T4), when compared with (T1). NBT assay used to determine the activity of phagocytes especially neutrophils and monocytes. The significant increase in NBT values, may be attributed to its anti-oxidant properties of Ocimum basilicum reported by Lee and Ahn, (1998).

The lysozyme is a fish defense element, which causes hydrolysis of the $\mathrm{N}$-acetylmuramic acid and $\mathrm{N}$-acetylglucosamine which are constituents of the peptidoglycan layer of bacterial cell wall and activation of the complement system and phagocytes by acting as an opsonin (Ellis, 1999 and Magnado' ttir, 2006). In this study Ocimum basilicum significantly increased the serum lysozyme activity, so it stimulated the immune response in Nile tilapia. The increased lysozyme activity has been reported after supplementing the fish-feed, with non-specific immunostimulants. The Ocimum basilicum significantly increased the serum bactericidal activity, against Aermonas hydrophilla. The common carp treated with herbal immunostimulant (Ocimum basilicum, Cinnamomum zeylanicum, Juglans) enhanced bactericidal activity, serum lysozyme, respiratory burst activity and hemoglobin (Abasalh, and Mohammad, 2010).

There were significant decreased in total bacterial count of fish muscle in T2 and T3 in compared with the control that may be due to the antimicrobial effect of basil oil. Suppakula et al., (2003) reported that basil essential oils exhibited good antimicrobial activity against a wide range of microorganisms . It is important to estimate the relative level of protection in the treated fish to determine the efficacy of an immunostimulant. The supplemented diet groups reduced mortality 
which induced by A. hydrophilla when compared with the control group. These results indicate that the basil oil activated the immune system of the Nile tilapia and it became resistance to pathogenic bacteria. Wannissorn et al., (2005) reported that $O$. basilicum essential oil showed moderate antibacterial activity and Abasalh, and Mohammad, (2010) mentioned that $O$. basilicum enhanced the bactericidal activity.

From the previously recorded results, It could be concluded that the potential of basil oil use as ecofriendly alternative measures of prevention of infectious diseases. This practice may reduce the sideeffects of applying the synthetic compounds and the cost and also make it ecofriendly which will increase the sustainability of fish culture. However, comprehensive knowledge regarding the ideal dose, duration, mode of administration and molecular basis behind the functional activity of different plant bioactive principles is necessary for complete understanding of the therapeutic potential of these compounds.

\section{Reference}

Abasalh, H., Mohammad, S. (2010). Immunostimulants diets. Journal of Animal and Veternnery Advances. 9(13), 1839-1847.

Albuquerque, U.P. (1996): de Taxonomia e ethnobotânica do gênero Ocimum L. (Lamiaceae) no Nordeste do Brasil-renfêrencia especial para Pernambuco. Recife. Dissertação (Mestrado em Biologia Vegetal)- Centro de Ciencias Biológicas, Universidade Federal de Pernambuco, p 125.

American Public Health Assciation (APHA) (1995). Standard methods for the examination of dairy products, 14th ed., American Public Health Association, Washington D.C.

Anderson, D.P., (1992). Immunostimulants, adjuvants and vaccine carries in fish; applications to aquaculture. Ann. Rev. Fish Disease. 2, 281- 307.

Bozin B, Mimica-Dukic N, Simin N, Anackov G (2006). "Characterization of the volatile composition of essential oils of some lamiaceae spices and the antimicrobial and antioxidant activities of the entire oils". J. Agriculture. Food Chemistry. 54 (5): 1822-8.

Cañada, F.C., Muñoz de la Peña, A., Mansilla, A.E.( 2009). Analysis of antibiotics in fish samples. Analytical and Bioanalytical Chemistry, 395:987-1008. 
Chakraborty, S.B. and Hancz, C. (2011). Application of phytochemicals as immunostimulant, antipathogenic and antistress agents in finfish culture. Reviews in Aquaculture, 3: 103-119.

Dambolena, J.S.. Zunino, M.P López, A.G. Rubinstein, H.R. Zygadlo J.A.,. Mwangi J.W, (2010).Essential oils composition of Ocimum basilicum L. and Ocimum gratissimum L. from Kenya and their inhibitory effects on growth and fumonisin production by Fusarium verticillioides. Innovative Food Science and Emerging Technologies, 11, pp. 410-414.

Dzida, K. (2010) Biological value and essential oil content in sweet basil (Ocimum basilicum L.) depending on calcium fertilization and cultivar. Acta Sci Pol Hortorum Cultus 9: 153-161.

Ellis, A.E., (1999). Immunity to bacteria in fish. Fish Shellfish Immunol. 9, 291-308.

Harikrishnan R., Heo J., Balasundaramb C., Kim M. C., Kim J. S., Han Y.J., and Heo M.S (2010). Effect of Punica granatum solvent extracts on immune system and disease resistance in Paralichthys olivaceus against lymphocystis disease virus (LDV). Fish \& Shellfish Immunology 29: 668-673.

Hassanpouragh dam., B.M., Hassani., A., Shalamzari S.M., (2010). Menthone and Estragole rich essential oil of cultivated Ocium basillicum 1. from Northwest Iran chemija. 21 (1 ) : 59- 62.

Haylor, G. and Bland, S. (2001): Integrating aquaculture into rural development in coasta Linland areas. In aquaculture in the third millennium. Pp 73-92.

Ismail M. (2006). Central properties and chemical composite on of Ocimum basilicum essential oil. Pharm Bioliology;44:619-26.

Jian J. and Wu Z. (2003). Effect of traditional Chinese medicine on nonspecific immunity and disease resistance of larvae of yellow croaker Pseudosciaena crocea (Richardson)". Aquaculture 218, 19.

Koba, A; Ishii, N; Mori, S; Fine, PE (2009) The decline of leprosy in Japan: patterns and trends 1964-2008. Leprosy review, 80 (4). pp. 432-40. ISSN 0305-7518

Lee HS, Ahn YJ. (1998), rowing-inhibiting effects of Cinnamomum cassia bark derived materials on human intestinal bacteria. $\mathbf{J}$ Agriculture Food Chemsitry; 46:8-12. 
Lina P Roldán1, MV; Gonzalo Jennifer M Duringer2, PC, PhD (2010). Composition and antibacterial activity of essential oils obtained from plants of the Lamiaceae family against pathogenic and beneficial bacteria. 23:451-461.

Magnadóttir, B., (2006). Innate immunity of fish (overview). Fish Shellfish Immunol. 20, 137-151.

Marotti M, Piccaglia R, Giovanelli E (1996) Differences in essential oil composition of basil (Ocimum basilicum L.) Italian cultivars related to morphological characteristics. J Agriculture Food Chemistry . 44: 3926-3929.

Mathew, S. and Kuttan,G.(1999).immunomodulatory and antitumar activities of Tinospora cardifolia. Fitoterpia. 70:35-43.

Naguyen.L, VanDongen, W., DeBracker, J., Deposter, H., High. ( 2008 ). Performance liquid chromatographic separation of naturally occurring esters of phenolic acids. Journal of chromatography Ageing research review . $187: 181-7$.

Özek T, Tabanca N, Demirci F, Wedge DE, Başer KHC (2010) Enantiomeric distribution of some linalool containing essential oils and their biological activities. 4: 180-192.

Peana AT, D'Aquila PS, Panin F, Serra G, Pippia P, Moretti MDL (2004) Anti-inflammatory activity of linalool and linalyl acetate constituents of essential oils. 9: 721-726.

Petersen, A.; Andersen, J.S.; Kaewmak, T.; Somsiri, T.; Dalsgaard, A. (2002): Impact of Integrated Fish Farming on Antimicrobial Resistance in a Pond Environment. Appl. Environ. Microbiol. 68 (12), 6036-6042.

Robertson, P. A. W., C. Odowd, P.Williams and B. Austin. (2000). Use of Carnobacterium sp. As a probiotic for Atlantic salmon ( Salmo salar) and rainbow trout, Oncorhyncus mykiss(Walbaum). Aquaculture 185, 235-243.

Sakai, M. 1999. Current research status of fish immunostimulants. Aquaculture. 172, 63-92.

Schaperclaus, W., Kulow, H., and Schreckenbach, K.,(1992). Fish Disease. Rotterdam, the Netherlands: A.A. Balkema. 101-105.

Seidler-Łożykowska K, Król D (2008) The content of essential oil in ten sweet basil (Ocimum basilicum L.) cultivars and its composition. 54: 7-12. 
Sifola MI, and Barbieri G (2006) Growth, yield, and essential oil content of three cultivars of basil grown under different levels of nitrogen in the field. Science Hort 108: 408-413.

Sivaram V, Babu M.M.,C itarasu T, Immanuel G,Murugadass S and Marian MP(2004). Growth and immune response of juvenile greasy groupers (Epinephelus tauvina) fed with herbal antibacterial active principle supplemented diets against Vibrio harveyi infection. Aquaculture 237:9-20.

Siwicki, A.K., Studnicka, M., and Ryka,B.,( 1985). Phagocytic ability of neutrophils in carp. Bamidgeh. 37, 123-128.

Siwicki, A.K., Anderson, D.P., Rumsey, G.L., (1994). Dietary intake of immunostimulants by rainbow trout affects non-specific immunity and protection against furunculosis. Immunology. 41, 125-139.

Stajkovic O, Beric-Bjedov T, Mitic-Culafic D, Stankovic S, VukovicGracic B, Simic D, Knezevic-Vukcevic J. (2007). Antimutagenic properties of basil (Ocimum basilicum L.) in Salmonella typhimurium TA100. Food Biotechnology.;45:213-7.

Suppakul, P. Miltz, J., Sonneveld, K., and Bigger, S.W. (2003) . Antimicrobial properties of basil and its possible application in food packing. Journal of Agriculture and food chemistry. 51, 397 3207.

Veenstra, J.; Rietra, P. J.; Stoutenbeek, C. P.; Coster, J. M.; De Hier, H. H. and Drisks-Go, S. (1992) Infection by an indole-negative variant of $V$. vulnificus transmitted by eels. J. Infection Disease., 16: 209-210.

Wannissoin, B., Jarkasern, S., Siriwangchai, T., and Thubthimthed, S. ( 2005 ). Antibacterial properties of essential oils from thai medicinal plants. Fitoterapia, 76, 233- 236.

Woo, P. T. K. and Bruno, D. W. (1999) Fish Diseases and Disorders. Vol. 3, Viral, Bacterial and Fungal infections. CABI Publishing, London, New York. 


\section{تاثير زيت الريحان علي الأستجابة المناعية الغير متخصصة في اسماك

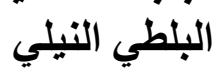

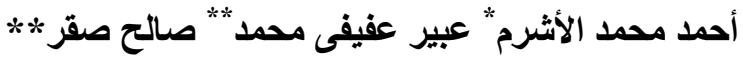

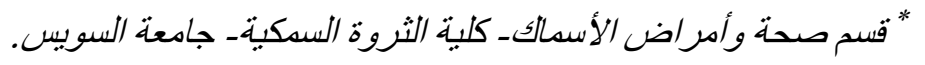

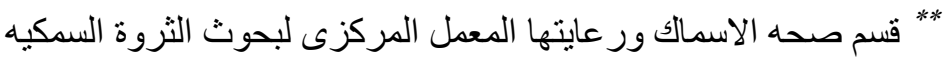

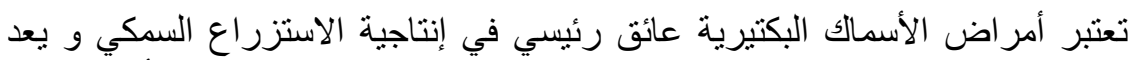

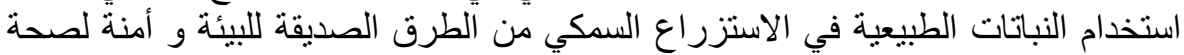

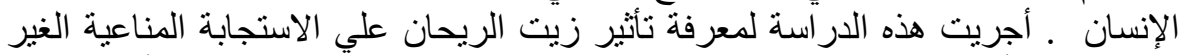

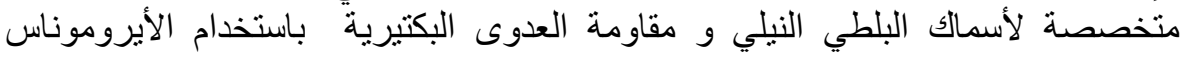
هيدروفيلا .

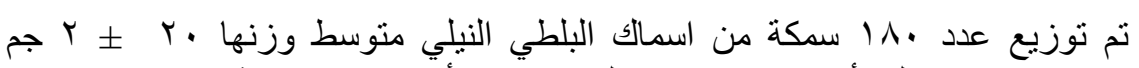

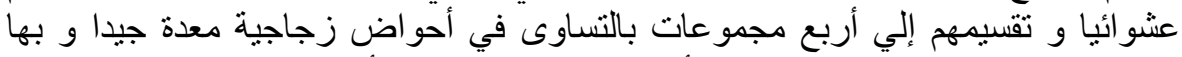

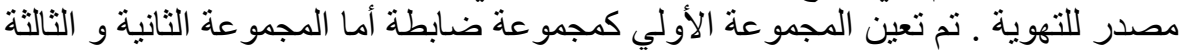

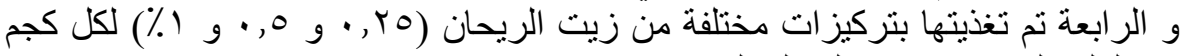

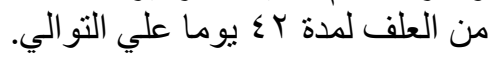

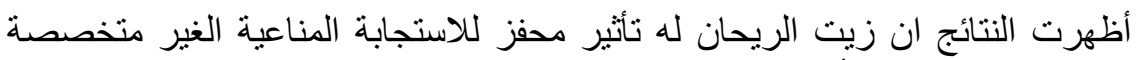

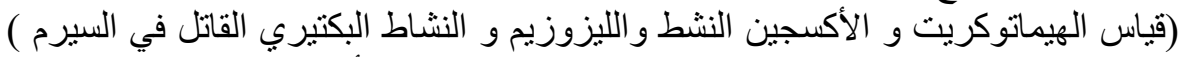

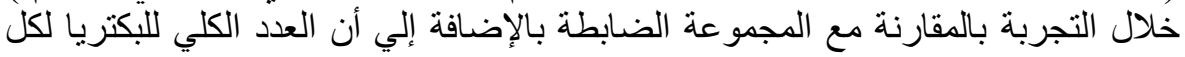

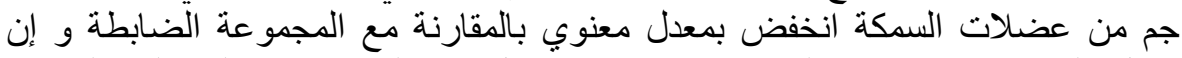

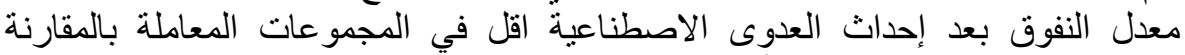

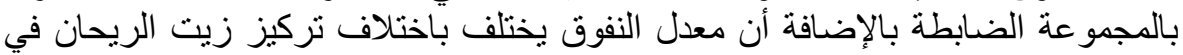

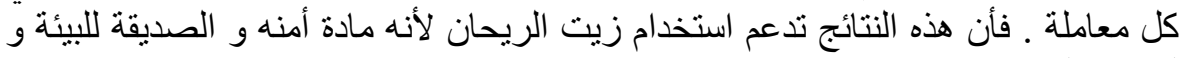

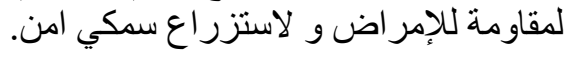

